\title{
An alternative method for production of microalgal biodiesel using novel Bacillus lipase
}

\author{
Duraiarasan Surendhiran • Abdul Razack Sirajunnisa • \\ Mani Vijay
}

Received: 12 October 2014 / Accepted: 13 December 2014/Published online: 7 January 2015

(C) The Author(s) 2015. This article is published with open access at Springerlink.com

\begin{abstract}
In this study, enzymatic interesterification is carried out using encapsulated lipase as biocatalyst with methyl acetate as acyl acceptor in a solvent-free system. Lipase, isolated from a marine bacterial isolate, Bacillus sp.S23 (KF220659.1) was immobilized in sodium alginate beads. This investigation elaborated on the effects of various parameters, namely enzyme loading, temperature, water, molar ratio, reaction time and agitation for interesterification. The study resulted in the following optimal conditions: $1.5 \mathrm{~g}$ immobilized lipase, 1:12 molar ratio of oil to methyl acetate, $35{ }^{\circ} \mathrm{C}, 8 \%$ water, $60 \mathrm{~h}$ reaction time, $250 \mathrm{rpm}$ of agitation. With the standardized condition, the maximum conversion efficiency was $95.68 \%$. The immobilized beads, even after ten cycles of repeated usage showed high stability in the presence of methyl acetate and no loss of lipase activity. The microalgal biodiesel composition was analyzed using gas chromatography. The current study was efficient in using immobilized lipase for the interesterification process, since the method was costeffective and eco-friendly, no solvent was involved and the enzyme was encapsulated in a natural polymer.
\end{abstract}

Keywords Biodiesel - Nannochloropsis oculata . Immobilized lipase · Encapsulation · Interesterification

\section{Introduction}

Alternative fuel has become a burgeoning global interest due to the deterioration and great consumption of fossil

D. Surendhiran $(\bowtie) \cdot$ A. R. Sirajunnisa $\cdot$ M. Vijay Bioprocess Laboratory, Department of Chemical Engineering, Annamalai University, Annamalainagar 608002,

Tamilnadu, India

e-mail: suren_micro@yahoo.co.in fuels leading to accumulation of greenhouse gases which paves the way for global warming ( $\mathrm{Su}$ et al. 2007). Biodiesel (monoalkyl esters of long chain fatty acids) is a potential renewable biofuel and it is biodegradable and non-toxic, has no net carbon dioxide and is free from sulfur (Ali et al. 2011; Jeong and Park 2008; Kim et al. 2011; Li and Yan 2010). Generally, biodiesel is produced from food and oil crops using conventional methods (Tran et al. 2013); however, these sources cannot realistically satisfy the wide use of diesel fuel due to increasing population, which leads to serious land shortage and raises the issue of food security (Surendhiran and Vijay 2012). Microalgae have become a recent attraction because of their high oil content; they can be grown in wastewater, do not compete with food crops for arable land and water and give 20 times more biomass productivity rate than terrestrial crops (Ashokkumar and Rengasamy 2012; Chisti 2007; Lai et al. 2012; Mutanda et al. 2011; Pittman et al. 2011; Vandamme et al. 2010). Microalgae are photosynthetic microorganisms that utilize light, water and $\mathrm{CO}_{2}$ and accumulate intracellular lipids as storage materials (Xiao et al. 2010).

Currently, biodiesel is being produced by acid and alkali transesterification that results in conversion of triglycerides to fatty acid methyl esters in a shorter period (Jegannathan et al. 2010; Shao et al. 2008). Demerits of such methods include high energy input, elimination of salt, difficulty in recycling glycerol, soap formation and the need of wastewater treatment (Ban et al. 2002; Al-Zuhair et al. 2007; Bisen et al. 2010; Jeon and Yeom 2010; Kawakami et al. 2011; Ognjanovic et al. 2009; Rodriques and Zachia Ayub 2011; Yoshida et al. 2012). To overcome this problem, enzymatic production of biodiesel has become an alternative for biodiesel production, because the by-product glycerol can be easily recovered, salt and catalyst can be avoided, wastewater treatment is not required, it gives high 
production yield under milder conditions and is a ecofriendly process (Gharat and Rathod 2013; Gumbyte et al. 2011; Salum et al. 2010). One such enzyme used in biodiesel production is lipases. Lipases (triacylglycerol acylhydrolase, EC 3.1.1.3) are produced by microorganisms, plants and animals, out of which microorganisms are highly suitable for the large scale production (Antczak et al. 2009). Lipases are denoted as the most industrially important enzymes next to bacterial amylases. These are primarily used for catalyzing hydrolytic and ester-synthesizing reactions. It has been widely implemented in food and pharmaceutical sectors, and in various reactions such as acidolysis, aminolysis, alcoholysis, esterification and hydrolysis of triglycerides (Sivaramakrishnan and Muthukumar 2012).

However, the enzymatic production of biodiesel has not yet been commercialized due to the high cost of the enzyme. The problem can be overcome by immobilization of lipase by repeated use (Liu et al. 2012; Maceiras et al. 2009; Tamalampudi et al. 2008). In addition, transesterification is usually performed by methanol, but it deactivates the lipase enzyme resulting in poor yield of biodiesel. In this study, methyl acetate had been used as an acyl acceptor instead of methanol and the by-product was triacetin (triacetylglycerol) instead of glycerol. Triacetin (triacetylglycerol) is used mainly as gelatinizing agents in polymers and explosives and as additive agent in tobacco, pharmaceutical industries and cosmetics (Maddikeri et al. 2013). Presently, there has been a worldwide focus on the production of biodiesel in a solvent-free system using lipase. These systems are advantageous over solvent-aided transesterification, as separation processes, toxicity, flammability and high cost of organic solvents can be avoided.

\section{Materials and methods}

\section{Culture conditions}

Nannochloropsis oculata was obtained from CMFRI, Tuticorin, Tamil Nadu, India and cultivated in a $200 \mathrm{~L}$ photobioreactor (PBR) using sterile Walne's medium. The filtered sterilized seawater was enriched with the required quantity of Walne's medium containing: $\mathrm{NaNO}_{3}$, $100 \mathrm{~g} \mathrm{~L}^{-1} ; \quad \mathrm{NaH}_{2} \mathrm{PO}_{4} \cdot 2 \mathrm{H}_{2} \mathrm{O}, \quad 20.0 \mathrm{~g} \mathrm{~L}^{-1} ; \quad \mathrm{Na}_{2}$ EDTA, $4.0 \mathrm{~g} \mathrm{~L}^{-1} ; \mathrm{H}_{3} \mathrm{BO}_{3}, 33.6 \mathrm{~g} \mathrm{~L}^{-1} ; \mathrm{MnCl}_{2} \cdot 4 \mathrm{H}_{2} \mathrm{O} \mathrm{g} \mathrm{L}^{-1}$, $0.36 \mathrm{~g} \mathrm{~L}^{-1} ; \mathrm{FeCl}_{3} \cdot 6 \mathrm{H}_{2} \mathrm{O}, \quad 13.0 \mathrm{~g} \mathrm{~L}^{-1} ;$ vitamin $\mathrm{B}_{12}$, $0.001 \mathrm{~g} \mathrm{~L}^{-1}$, vitamin $\mathrm{B}_{1}, 0.02 \mathrm{~g} \mathrm{~L}^{-1}$ and trace metal solution $1 \mathrm{ml}$. The trace metal solution contained: $\mathrm{ZnSO}_{4} \cdot 7 \mathrm{H}_{2} \mathrm{O}, \quad 21 \mathrm{~g} \mathrm{~L}^{-1} ; \mathrm{CoCl}_{2} \cdot 6 \mathrm{H}_{2} \mathrm{O}, \quad 20 \mathrm{~g} \mathrm{~L}^{-1}$; $\left(\mathrm{NH}_{4}\right)_{6} \mathrm{Mo}_{7} \mathrm{O}_{24} \cdot \mathrm{H}_{2} \mathrm{O}, \quad 9 \mathrm{~g} \mathrm{~L}^{-1} ;$ and $\mathrm{CuSO}_{4} \cdot 5 \mathrm{H}_{2} \mathrm{O}$, $20 \mathrm{~g} \mathrm{~L}^{-1}$. The medium was adjusted to $\mathrm{pH} 8$ and autoclaved at $121{ }^{\circ} \mathrm{C}$ for $20 \mathrm{~min}$. The filter-sterilized vitamins were added after cooling. Mixing was provided by sparging air from the bottom of the PBR and lighting was supplied by cool-white fluorescent light with an intensity of 5,000 lux under 12/12 light/dark cycle for 15 days. The medium was supplied with nitrogen for the first 4 days, after which the nutrients were added to PBR without nitrogen to create a nitrogen stress environment condition to produce more oil.

Isolation and screening of lipase-producing bacteria from marine sediments

The lipase-producing bacteria were isolated from marine sediment at Parangipettai, a coastal area of Tamil Nadu, India. The samples were collected from sediment $(5 \mathrm{~cm}$ depth) using a sterile container and immediately transferred to laboratory, serially diluted and spread on (medium composed of: peptone, $10 \mathrm{~g} \mathrm{~L}^{-1} ; \mathrm{NaCl}, 5 \mathrm{~g} \mathrm{~L}^{-1}$; $\mathrm{CaCl}_{2} \cdot 2 \mathrm{H}_{2} \mathrm{O}, 0.1 \mathrm{~g} \mathrm{~L}^{-1}$; agar-agar, $20 \mathrm{~g} \mathrm{~L}^{-1}$; Tween 20, $10 \mathrm{~mL}(\mathrm{v} / \mathrm{v}))$ agar plates followed by incubation for $24 \mathrm{~h}$ at $37{ }^{\circ} \mathrm{C}$. Lipase-producing bacteria produced a zone of clearance which was observed under UV transilluminator. Then the bacterial strain was isolated and subcultured using nutrient agar with $1 \%$ olive oil and $3 \% \mathrm{NaCl}$ and subjected to studying morphological, cultural, spore production and biochemical characteristics.

Gene sequence for molecular identification of the isolated strain

The molecular identification of the characterized culture was done by analyzing the genomic DNA. PCR analysis was performed with $16 \mathrm{~S}$ rRNA primers: $27 \mathrm{~F}\left(5^{\prime}\right.$-AGA GTT TGA TCC TGG CTC AG-3') and 1492R (5'- TAC GGT TAC CTT GTT ACG ACT T-3'). A volume of $25 \mu \mathrm{l}$ reaction mixture for $\mathrm{PCR}$ was carried out using $10 \mathrm{ng}$ of genomic DNA, $1 \mathrm{X}$ reaction buffer $(10 \mathrm{mM}$ Tris- $\mathrm{HCl} \mathrm{pH}$ 8.8, $1.5 \mathrm{mM} \mathrm{MgCl}_{2}, 50 \mathrm{mM} \mathrm{KCl}$ and $0.1 \%$ Triton $\left.\mathrm{X}-100\right)$, $0.4 \mathrm{mM}$ dNTPs each, $0.5 \mathrm{U}$ DNA polymerase and $1 \mathrm{mM}$ reverse and forward primers each. The reaction was performed in 35 amplification cycles at $94{ }^{\circ} \mathrm{C}$ for $45 \mathrm{~s}, 55^{\circ} \mathrm{C}$ for $60 \mathrm{~s}, 72{ }^{\circ} \mathrm{C}$ for $60 \mathrm{~s}$ and an extension step at $72{ }^{\circ} \mathrm{C}$ for $10 \mathrm{~min}$. The sequencing of $16 \mathrm{~S}$ amplicon was performed according to the manufacturer's instructions of the Big Dye terminator cycle sequencing kit (Applied BioSystems, USA). Sequencing products were resolved on an Applied Biosystems model 3730XL automated DNA sequencing system (Applied BioSystems, USA). The 16S rRNA gene sequence obtained from the organism was compared with other Bacillus strains for pairwise identification using NCBI-BLAST (http://blast.ncbi.nlm.nih.gov/Blast.cgi) and multiple sequence alignments of the sequences were performed using Clustal Omega version of EBI (www.ebi.ac. uk/Tools/msa/clustalo). Phylogenetic tree was constructed 
by Clustal Omega of EBI (www.ebi.ac.uk/Tools/ phylogeny/clustalw2_phylogeny) using neighbor joining method.

Harvesting of cells and oil extraction

After the culture reaches the stationary phase at the 15th day (the culture was checked for growth every $24 \mathrm{~h}$ ), the biomass was harvested using marine B. subtilis (MTCC 10619) to get thick microalgal paste as reported in our previous work (Surendhiran and Vijay 2014a, b). The dried biomass was subjected to oil extraction by Bligh and Dyer (1959) technique with slight modification. In brief, the biomass suspension was mixed with chloroform: methanol (1:2) ratio, vortexed for few minutes and incubated on ice for $10 \mathrm{~min}$. Then, chloroform was added followed by addition of $1 \mathrm{M} \mathrm{HCl}$ and again vortexed for a few minutes. Finally, the whole suspension was centrifuged at a maximum speed of 12,000 rpm for $2 \mathrm{~min}$. The bottom layer containing lipid was transferred into a fresh, previously weighed beaker. Chloroform was added to reextract the lipid from the aqueous sample. The solvent system was evaporated using a rotary evaporator at $30{ }^{\circ} \mathrm{C}$. The final product, lipid, was collected in a screw cap vial and stored at room temperature.

Fermentation of lipase production using isolated strain

Lipase production was carried out in a $250 \mathrm{ml}$ Erlenmeyer flask using $100 \mathrm{ml}$ basal medium containing $1 \%$ olive oil, $0.2 \% \quad \mathrm{CaCl}_{2} \cdot 2 \mathrm{H}_{2} \mathrm{O}, \quad 0.01 \% \quad \mathrm{MgSO}_{4} \cdot 7 \mathrm{H}_{2} \mathrm{O}, \quad 0.04 \%$ $\mathrm{FeCl}_{3} \cdot 6 \mathrm{H}_{2} \mathrm{O}$ and $5 \% \mathrm{NaCl}$, with $2 \mathrm{ml}$ of starting inoculum. The contents were incubated for $48 \mathrm{~h}$ at $37{ }^{\circ} \mathrm{C}$ at $200 \mathrm{rpm}$ and $\mathrm{pH}$ 7. After incubation, the culture was centrifuged at $10,000 \mathrm{rpm}$ for $10 \mathrm{~min}$ at $4^{\circ} \mathrm{C}$. The supernatant of crude lipase was quantified using lipase assay and used for immobilization.

Immobilization of crude lipase

Crude lipase $(6 \mathrm{ml})$ was mixed with $14 \mathrm{ml}$ of sodium alginate solution $(2 \%)$. The mixer was dripped into cold sterile $0.2 \mathrm{M} \mathrm{CaCl}_{2}$ using sterile syringe from a constant distance and was cured at $4{ }^{\circ} \mathrm{C}$ for $1 \mathrm{~h}$. The beads were hardened by suspending it again in a fresh $\mathrm{CaCl}_{2}$ solution for $24 \mathrm{~h}$ at $4{ }^{\circ} \mathrm{C}$ with gentle agitation. After immobilization, the beads were separated by filtration and washed with $25 \mathrm{mM}$ phosphate buffer ( $\mathrm{pH}$ 6.0) to remove excess calcium chloride and enzyme. Then the beads were preserved at $18{ }^{\circ} \mathrm{C}$ using $0.9 \% \mathrm{NaCl}$ solution for future use (Kavardi et al. 2012; Vimalarasan et al. 2011).
Lipase assay and protein determination

Lipase activity was determined for free and immobilized enzymes according to Burkert et al. (2004) and Padilha et al. (2012). The olive oil emulsion was prepared by mixing $25 \mathrm{ml}$ of olive oil and $75 \mathrm{ml}$ of $7 \%$ Arabic gum solution in a homogenizer for $5 \mathrm{~min}$ at $500 \mathrm{rpm}$ at room temperature. The reaction mixture containing $5 \mathrm{ml}$ of emulsion, $2 \mathrm{ml}$ of $10 \mathrm{mM}$ phosphate buffer ( $\mathrm{pH} 7.0$ ) and $1 \mathrm{ml}$ of the culture supernatant was incubated at $37^{\circ} \mathrm{C}$ for $30 \mathrm{~min}$ in an orbital shaker. The reaction was stopped by addition of $15 \mathrm{ml}$ of acetone-ethanol (1:1v/v), and the liberated fatty acids were titrated with $0.05 \mathrm{~N} \mathrm{NaOH}$. One unit of lipase activity was defined as the amount of enzyme that liberated $1 \mu \mathrm{mol}$ of fatty acid per minute. The protein content in the crude enzyme was determined by Lowry et al.'s (1951) method with BSA as standard. The same procedure was done with $1 \mathrm{~g}$ of immobilized lipase to determine the percentage of immobilization according to Kavardi et al. (2012). The presence of protein in crude lipase was identified using sodium dodecyl sulfate-polyacrylamide gel electrophoresis (SDS-PAGE) with $12 \%$ polyacrylamide gel.

Determination of molecular weight of microalgal oil

According to Sathasivam and Manickam (1996), the saponification and acid value of microalgal oil were determined. The molecular weight of the oil was calculated as in $\mathrm{Xu}$ et al. (2006), the formula being:

$M=\frac{168,300}{\mathrm{SV}-\mathrm{AV}}$

where $M$ is the molecular weight of the oil, SV the saponification value and $\mathrm{AV}$ the acid value.

Optimization of enzyme transesterification process by a solvent-free system

The enzymatic transesterification reaction was carried out in a $20 \mathrm{ml}$ screw cap glass bottle. No solvent was added in this reaction. The reaction mixture consisted of $3 \mathrm{~g}$ of microalgal oil and $1 \mathrm{~g}$ of immobilized enzyme and methyl acetate. The oil to acyl acceptor (methyl acetate) was optimized ranging from 1:4, 1:6, 1:8, 1:10, 1:12 and 1:14. The effect of temperature was studied at various ranges of $25,30,35$ and $40{ }^{\circ} \mathrm{C}$. To investigate the effect of water, enzymatic transesterification was carried out by adding small amounts of water, at concentrations of $0,2,4,6,8$ and $10 \mathrm{wt} \%$ of the total amount of the reaction mixture. The interesterification reaction was allowed for $48 \mathrm{~h}$ at a constant speed of $200 \mathrm{rpm}$. All the experiments were 
carried out in triplicate and the biodiesel yield was calculated according to Umdu et al. (2009).

Gas chromatographic analysis of fatty acid methyl esters

Fatty acid methyl ester composition of biodiesel produced from $N$. oculata oil was analyzed by gas chromatographymass spectrometry (GC-MS-QP 2010, Shimadzu) equipped with VF-5 MS capillary column (nonpolar, $30 \mathrm{~mm}$ length, $0.25 \mathrm{~mm}$ diameter and $0.25 \mu \mathrm{m}$ film thickness). The column temperature of each run was started at $70{ }^{\circ} \mathrm{C}$ for $3 \mathrm{~min}$, then raised to $300{ }^{\circ} \mathrm{C}$ and maintained at $300{ }^{\circ} \mathrm{C}$ for $9 \mathrm{~min}$. GC conditions were: column oven temperature, $70{ }^{\circ} \mathrm{C}$; injector temperature, $240{ }^{\circ} \mathrm{C}$; injection mode, split; split ratio, 10; flow control mode, linear velocity; column flow, $1.51 \mathrm{ml} / \mathrm{min}$; carrier gas, helium (99.9995 \% purity); and injection volume, $1 \mu \mathrm{l}$. MS conditions were: ion source temperature, $200{ }^{\circ} \mathrm{C}$; interface temperature, $240{ }^{\circ} \mathrm{C}$; scan range, $40-1,000 \mathrm{~m} / \mathrm{z}$; solvent cut time, $5 \mathrm{~min}$; MS start time, $5 \mathrm{~min}$; end time, $35 \mathrm{~min}$; ionization, EI $(-70 \mathrm{eV})$; and scan speed, 2,000.

\section{Results and discussion}

Identification and characterization of lipase-producing marine bacterial isolate using 16S rRNA gene sequencing

Lipase-producing bacteria produced a zone of clearance around colonies with calcium precipitation due to hydrolysis of lauric, myristic, palmitic and stearic acids present in the medium containing Tween 20 . The calcium precipitation was due to the formation of calcium salts and fatty acids released by the hydrolysis of lipase. The isolated marine sediment microorganism was analyzed by morphological and biochemical tests and found to be a Grampositive rod, producing spores. The results obtained through various biochemical tests showed that the bacterium belonged to Bacillus subtilis. 16S rRNA gene sequencing was performed to identify the species and strain; culture confirmed that it was Bacillus sp.S23 (KF220659.1) through the phylogenetic tree.

Quantification and characterization of microalgal oil

The oil content of $N$. oculata was calculated according to Suganya and Renganathan (2012) and the oil extraction yield was found to be $54.26 \mathrm{~g}(\% \mathrm{w} / \mathrm{w})$. The lipid concentration was defined as dry weight ratio of extracted lipids to biomass. The molecular weight of $N$. oculata oil was found to be 863.28 , calculated from the acid value (0.58) and saponification value (195.53).

Quantification of lipase assay and molecular weight determination of isolated lipase

The isolated marine Bacillus sp.S23 (KF220659.1) was used for lipase production at an optimum condition of $48 \mathrm{~h}$ at $40{ }^{\circ} \mathrm{C}$ at $200 \mathrm{rpm} .1 \%$ olive oil was used for enhancing lipase production. The lipase activity from the culture supernatant was found to be $9.26 \mathrm{Uml}^{-1}$. SDS-PAGE study revealed that the molecular weight of ammonium sulfate (40\% saturation)-purified extracellular lipase was nearly $20 \mathrm{kDa}$ and crude lipase was around $45 \mathrm{kDa}$, which was confirmed with a standard marker (Fig. 1). Generally, genus Bacillus produces various types of lipases, based on molecular weight of protein ranging between 15 and $60 \mathrm{kDa}$. In the current study the lipase has low molecular weight of $20 \mathrm{kDa}$, which might be due to the conservative peptides such as Ala-His-Ser-Met-Gly in the protein (Sivaramakrishnan and Muthukumar 2012).

\section{Effect of enzyme loading}

Effect of enzyme loading was studied to enhance transesterification in the range of $0.5-2.5 \mathrm{~g}$. Figure 2 shows that the increasing enzyme loading resulted in increase in biodiesel yield when the load of immobilized beads was $1.5 \mathrm{~g}$. The methyl ester yield was decreased at higher enzyme concentration. This is in agreement with Maceiras et al. (2009) and Jegannathan et al. (2010), who found that higher dosage of immobilized lipase results in lower yield

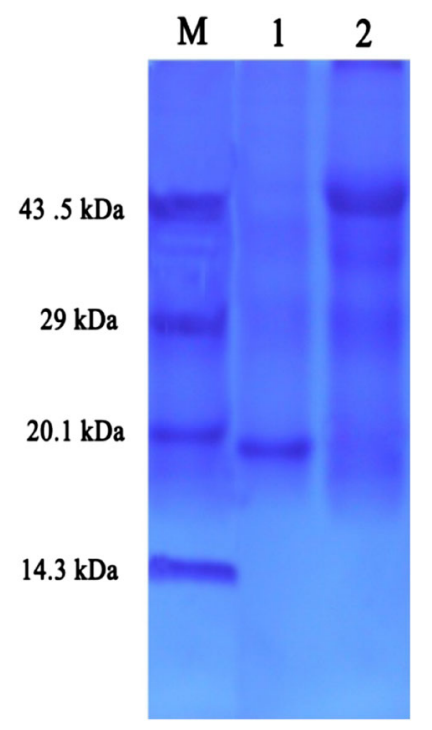

Fig. 1 SDS-PAGE study of lipase isolated from marine bacteria Bacillus sp.S23 (KF220659.1). Lane 1 protein marker, lane 2 alumpurified lipase and lane 3 crude lipase 


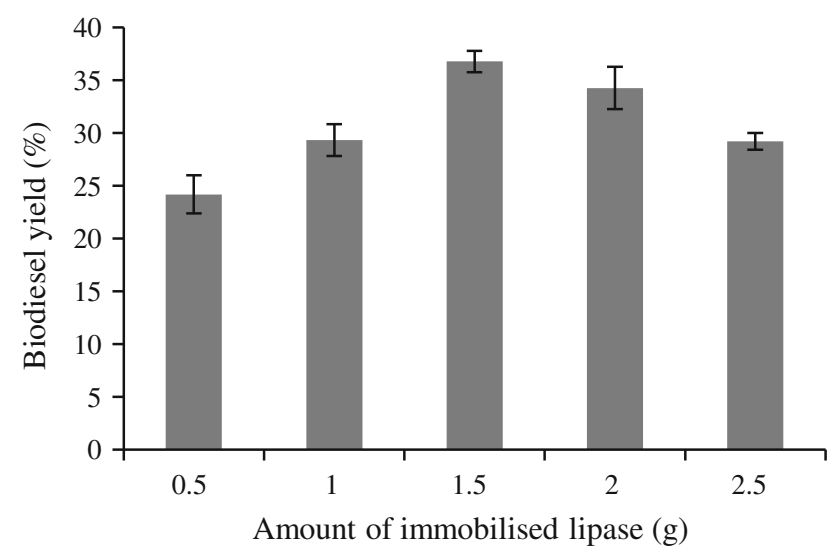

Fig. 2 Effect of immobilized lipase loading on biodiesel yield (\%). Reaction conditions: 1:4 oil/methyl acetate molar ratio, $30{ }^{\circ} \mathrm{C}$, $200 \mathrm{rpm}$ and $48 \mathrm{~h}$

of biodiesel. This is because the superfluous enzyme would unite and reduce the activity of lipase (Li and Yan 2010).

Effect of oil and methyl acetate molar ratio

The effect of oil and methyl acetate ratio was investigated. It was found that 1:12 molar ratio of oil to methyl acetate gave maximum fatty acid methyl esters yield of $67.34 \%$ at $48 \mathrm{~h}$ in the absence of any solvents, similar to previous study done by Ognjanovic et al. (2009). However, the biodiesel yield declined when the molar ratio was raised to 1:14 (Fig. 3), due to the excessive amount of methyl acetate that diluted the oil resulting in poor yield of fatty acid methyl esters. The conventional short chain alcohols such as ethanol and methanol inactivate the lipase enzyme when exceeding the 1:3 molar ratio. In support of this, Shimada et al. (1999) reported that inactivation of immobilized lipase Novozym 435 from $C$. antarctica occurred at a molar ratio of 1:5 of plant oil and methanol. In addition,

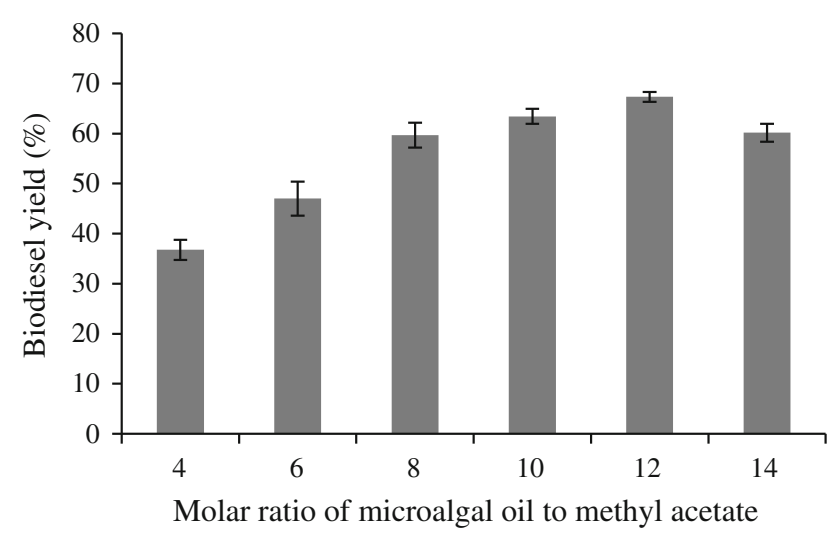

Fig. 3 Effect of molar ratio of methyl acetate to microalgal oil on biodiesel yield (\%). Reaction conditions: $1.5 \mathrm{~g}$ immobilized lipase, $30{ }^{\circ} \mathrm{C}, 200 \mathrm{rpm}$ and $48 \mathrm{~h}$ during methanolic transesterification, the main by-product is glycerol, which is hydrophilic in nature and insoluble in oil, resulting in a decrease in the reactivity of immobilized lipase due to mass transfer resistance (Tran et al. 2013; Xu et al. 2003; Ruzich and Bassi 2011). Methyl acetate produces triacetylglycerol instead of glycerol, which does not inactivate lipase (Ruzich and Bassi 2011).

\section{Effect of temperature}

To study the effect of temperature on the enzymatic biodiesel process, the range studied was between 25 and $40{ }^{\circ} \mathrm{C}$ with an interval of $5^{\circ} \mathrm{C}$. The temperature was not allowed to exceed $40{ }^{\circ} \mathrm{C}$, because sodium alginate dissolves at higher temperature. Tran et al. (2013) reported that FAME production decreased when the temperature increased to $50{ }^{\circ} \mathrm{C}$ for freshwater microalgae C. vulgaris ESP-31 by enzymatic transesterification. However, most of the enzymatic reaction does not require higher temperature (Jegannathan et al. 2010). In the current findings, $35{ }^{\circ} \mathrm{C}$ gave the highest yield of $73.79 \%$ (Fig. 4), thereby reducing the energy consumption since higher temperature had not been used.

\section{Effect of water}

For biocatalyst-mediated transesterification, water acts as a key factor for enhancing the lipase activity by increasing interfacial area of oil-water droplets (Li and Yan 2010; Liu et al. 2012; Tran et al. 2012). Lipase activity generally depends on the availability of interfacial area (Dizge and Keskinler 2008). Li and Yan (2010) reported that exceeding the water content over $7 \%$ of the total volume of the reaction mixture leads to decrease in the formation of FAME. However, in our study, there was no decrease of methyl esters until $8 \%$ water content was achieved, which

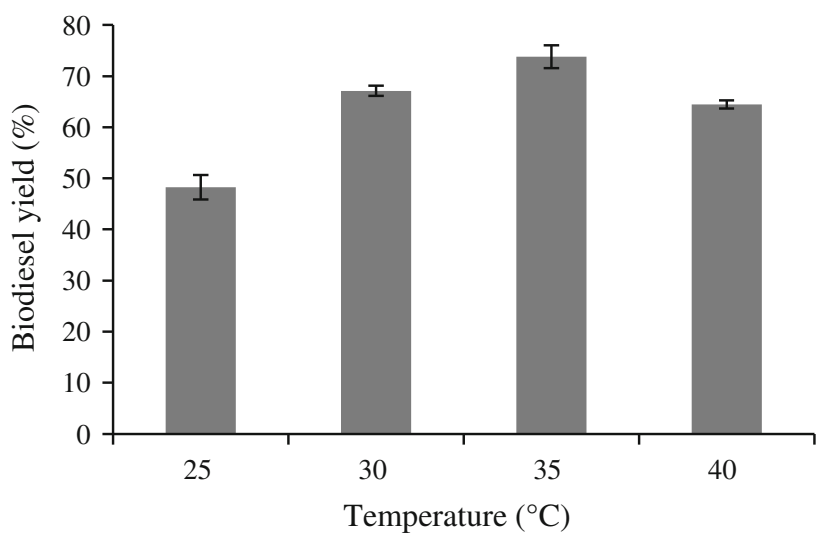

Fig. 4 Effect of temperature on biodiesel yield (\%). Reaction conditions: $1.5 \mathrm{~g}$ immobilized lipase, 1:12 oil/methyl acetate molar ratio, $200 \mathrm{rpm}$ and $48 \mathrm{~h}$ 
was due to the formation of triacylglycerol (triacetin) that did not disturb lipase activity. The highest yield of biodiesel was $85.36 \%$ at $8 \%$ water content. When the water content reached beyond $8 \%$, the yield was reduced (Fig. 5), due to the excess water content that reduced the transesterification reaction rate (Dizge and Keskinler 2008; Fukuda et al. 2006).

\section{Effect of reaction time on biodiesel yield}

Effect of reaction time was investigated in the range of 12-72 h. The optimized reaction time for conversion of microalgal oil to FAME by immobilized biocatalyst was found to be $60 \mathrm{~h}$ and the maximum yield was $89.48 \%$ (Fig. 6). Beyond the maximal reaction at $60 \mathrm{~h}$, a decrease in FAME was obtained. This is due to the increase in the water concentration during transesterification, which triggers the hydrolysis of the biodiesel (Jeong and Park 2008; Li and Yan 2010; Eevera et al. 2009; Leung et al. 2010).

\section{Effect of agitation speed}

Agitation is one of the important parameters in immobilized enzymatic transesterification. In the immobilization reaction system, the reactants need to diffuse from the bulk liquid to the external surface of the particle and then into the interior pores of the catalyst (Kumari et al. 2009). The effect of mixing on biodiesel production was conducted between 100 and $300 \mathrm{rpm}$ with an interval of $100 \mathrm{rpm}$. Figure 7 shows the methyl ester production rate with the respective speed of agitation. The maximum yield of biodiesel was found to be $95.68 \%$ at $250 \mathrm{rpm}$; thus, agitation enhances the rate of reaction. Agitation reduces the mass transfer resistance between oil and acyl acceptor and immobilizes lipase at the catalyzing interface, thus

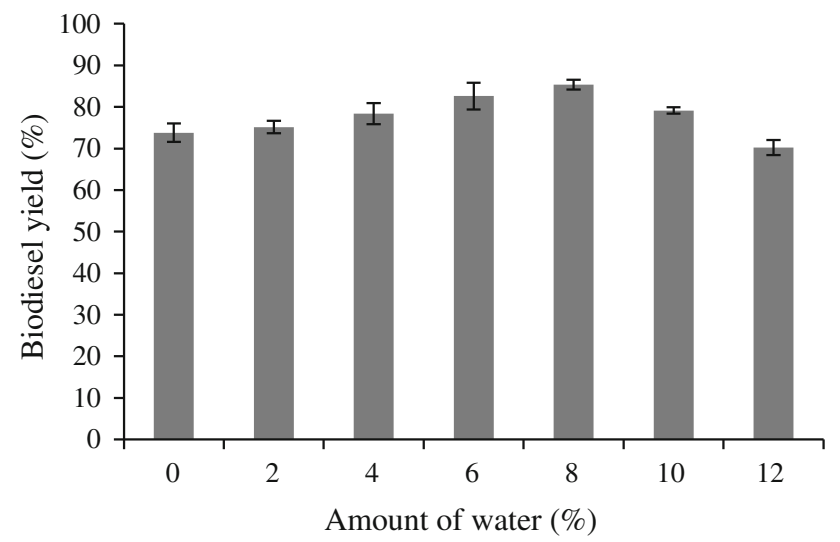

Fig. 5 Effect of water on biodiesel yield (\%). Reaction conditions: $1.5 \mathrm{~g}$ immobilized lipase, 1:12 oil/methyl acetate molar ratio, $35^{\circ} \mathrm{C}$, $200 \mathrm{rpm}$ and $48 \mathrm{~h}$ enhancing the reaction rate. On the other hand, when the speed reaches beyond $250 \mathrm{rpm}$, the biodiesel yield is decreased. This is due to the damage of the immobilized beads, leading to inactivation of lipase by mechanical agitation (Li and Yan 2010; Ognjanovic et al. 2009; Tran et al. 2012).

$\mathrm{Xu}$ et al. (2005) obtained a FAME yield of $67 \%$ at $40{ }^{\circ} \mathrm{C}$ from refined soybean oil during interesterification reaction carried out at atmospheric pressure, with an oil to methyl acetate molar ratio of $1: 12$ and a reaction time of $36 \mathrm{~h}$ using Novozym $(0.1 \mathrm{~g}$ of enzyme per $1 \mathrm{~g}$ of oil). Similarly, Usai et al. (2010) obtained $80 \%$ of fatty acid methyl esters from olive oil with the reaction conditions of oil to methyl acetate molar ratio of 1:20 using immobilized lipase Candida antarctica. In our current study, the total biodiesel was $95.68 \%$ at $1.5 \mathrm{~g}$ immobilized lipase, 1:12 molar ratio of oil to methyl acetate and at $35{ }^{\circ} \mathrm{C}$.

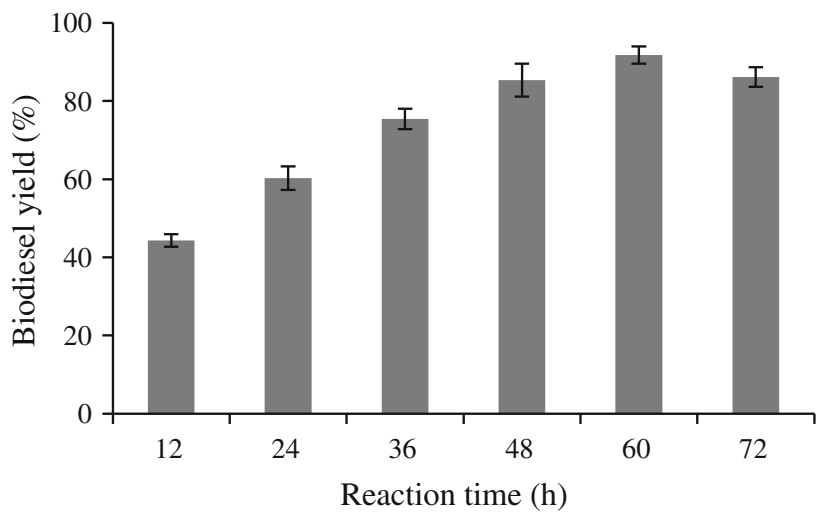

Fig. 6 Effect of reaction time (\%). Reaction conditions: 1.5 immobilized lipase, 1:12 oil/methyl acetate molar ratio, $4 \%$ water $(w / w)$ $35^{\circ} \mathrm{C}$ and $200 \mathrm{rpm}$

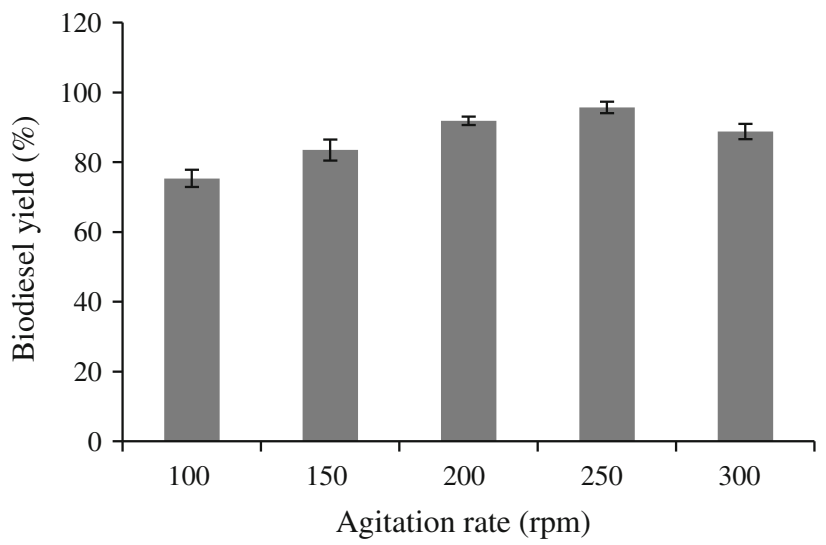

Fig. 7 Effect of agitation on biodiesel yield (\%). Reaction conditions: $1.5 \mathrm{~g}$ immobilized lipase, 1:12 oil/methyl acetate molar ratio, $4 \%$ water (w/w) $35{ }^{\circ} \mathrm{C}$ and $60 \mathrm{~h}$ 
Reusability of immobilized enzyme

The main advantage of immobilized enzyme is its reusability. Reusability of enzyme is the important parameter to decide the possibilities of industrial-scale enzymatic biodiesel production (Gharat and Rathod 2013). Stability and reusability of immobilized lipase from marine Bacillus sp.S23 (KF220659.1) was investigated in this section. There was no significant loss of lipase activity even after immobilized enzyme beads were used for ten cycles (Fig. 8). As previously reported by Du et al. (2004), no enzyme loss was found even after 100 cycles of repeated usage in the presence of methyl acetate. When short chain alcohols (methanol and ethanol) are used as acyl acceptor, removal of glycerol from immobilized lipase must be carried out using large amounts of hydrophilic solvents, which is a cost-effective process and inhibits lipase activity. Thus, the current study indicates that immobilized lipase can be used for many repeated cycles in biodiesel production from microalgal oil with methyl acetate as acyl acceptor, which will minimize the cost factor in the overall process.

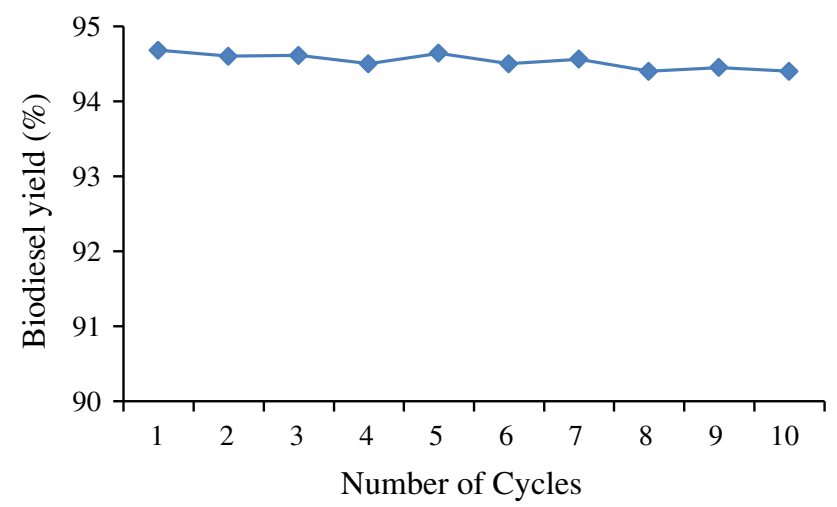

Fig. 8 Reusability and stability of immobilized lipase on biodiesel yield (\%). Reaction conditions: $1.5 \mathrm{~g}$ immobilized lipase, 1:12 oil/ methyl acetate molar ratio, $4 \%$ water $(\mathrm{w} / \mathrm{w}), 35^{\circ} \mathrm{C}, 250 \mathrm{rpm}$ and $60 \mathrm{~h}$
Analysis of FAME

The fatty acid composition of biodiesel synthesized from $N$. oculata grown under nitrogen-depleted condition was analyzed and compared with FAME produced from nitrogen-repleted culture using GC (Table 1).

From the retention time obtained by GC, peak values were analyzed and observed as myristic acid (C14:0), palmitic acid (C16:0), stearic acid (C18:0), oleic acid (C18:1), linoleic acid (C18:2) and arachidic acid (C20:0), which were commonly found in biodiesel synthesized from N. oculata oil (Fig. 9). However, under nitrogen starvation condition, the lipid content not only doubled but also gradually changed the fatty acid composition of $N$. oculata oil (Surendhiran and Vijay 2014a, b; Huang et al. 2010; Widjaja et al. 2009). Moreover, in N. oculata, the oleic acid content increased from 35.21 to $44.68 \%$ (Yoshida et al. 2012). This result was in better agreement with a previous study conducted by Zhila et al. (2005).

Unsaturated fatty acids have been reported to have a reasonable balance of fuel properties (Zheng et al. 2011). We have reported that the chain length of fatty acids in $N$. oculata was between C14 and C20 in our previously study (Surendhiran and Vijay 2014a, b). In a previous report, it was stated that fatty acids with maximum of C16 and C18 series were recognized as the most common components of biodiesel (Lin et al. 2012). Therefore, fatty acids from $N$. oculata were more applicable for producing a high quality of biofuel, since it contained a high content of C16 (palmitic acid) and C18 (oleic acid).

\section{Properties of biodiesel from N. oculata}

The properties of $N$. oculata biodiesel synthesized through interesterification are listed in Table 2. The results were compared with that of diesel fuel and biodiesel from jatropha oil as stated by ASTM standard D6751. The final results revealed that no substantial variations were observed between the biodiesel properties of $N$. oculata and jatropha oil.

Table 1 Fatty acid composition of $N$. oculata FAME under nitrogen-repleted and nitrogen-depleted growth

\begin{tabular}{|c|c|c|c|c|c|}
\hline Lipid number & Common Name & Systematic name & Molecular structure & Fatty acid $\left(\mathrm{N}^{+}\right) \%$ & Fatty acid $\left(\mathrm{N}^{-}\right) \%$ \\
\hline $\mathrm{C} 14: 0$ & Myristic acid & Tetradecanoic acid & $\mathrm{C}_{12} \mathrm{H}_{24} \mathrm{O}_{2}$ & 9.86 & 8.94 \\
\hline C16:0 & Palmitic acid & Hexadecanoic acid & $\mathrm{C}_{16} \mathrm{H}_{32} \mathrm{O}_{2}$ & 19.39 & 13.83 \\
\hline C18:0 & Stearic acid & Octadecanoic acid & $\mathrm{C}_{18} \mathrm{H}_{36} \mathrm{O}_{2}$ & 10.76 & 9.79 \\
\hline C18:1 & Oleic acid & 9-Octadecenoic acid & $\mathrm{C}_{18} \mathrm{H}_{34} \mathrm{O}_{2}$ & 35.21 & 44.68 \\
\hline C18:2 & Linoleic acid & 9,12-Octadecadienoic acid & $\mathrm{C}_{18} \mathrm{H}_{32} \mathrm{O}_{2}$ & 8.15 & 6.92 \\
\hline C20:0 & Arachidic acid & Eicosanoic acid & $\mathrm{C}_{18} \mathrm{H}_{30} \mathrm{O}_{2}$ & 16.62 & 15.84 \\
\hline
\end{tabular}

$N^{+}$presence of nitrogen, $N^{-}$absence of nitrogen 

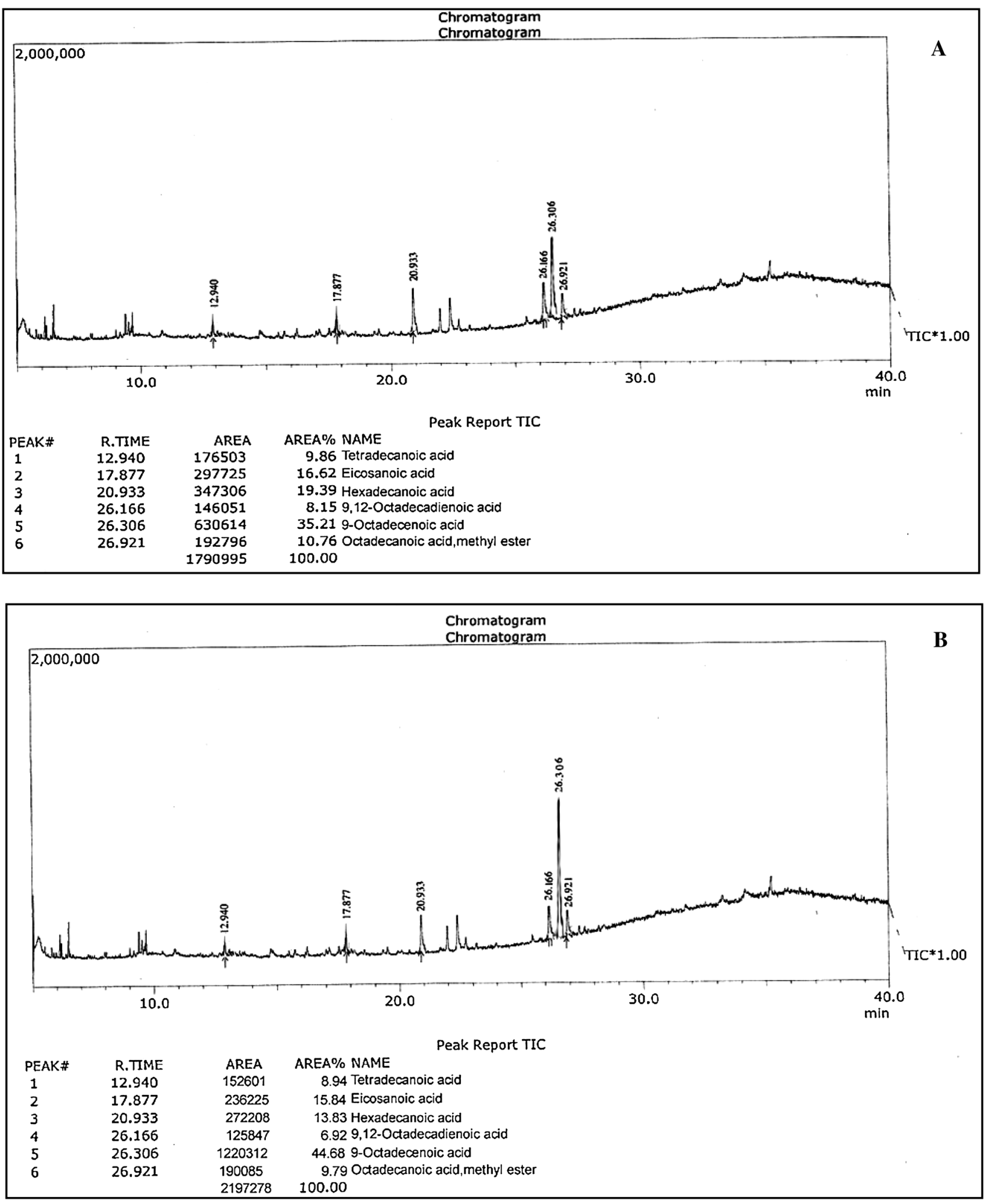

Fig. 9 GC-MS chromatograms of N.oculata FAME under nitrogen-repleted (a) and nitrogen-depleted (b) growth 
Table 2 Comparison of physio-chemical properties of biodiesel from $N$. oculata with petrodiesel and Jatropha biodiesel

\begin{tabular}{llll}
\hline Properties & $\begin{array}{l}\text { Diesel } \\
\text { fuel }\end{array}$ & $\begin{array}{l}\text { Biodiesel from } \\
\text { Jatropha }\end{array}$ & $\begin{array}{l}\text { Biodiesel from } \\
\text { N. oculata }\end{array}$ \\
\hline $\begin{array}{l}\text { Density }(\mathrm{g} / \mathrm{ml}) \\
\text { Kinematic viscosity } \\
\left(@ 40{ }^{\circ} \mathrm{C}\right)\end{array}$ & 0.841 & 0.865 & 0.871 \\
$\begin{array}{l}\text { Flash point }\left({ }^{\circ} \mathrm{C}\right) \\
\text { Fire point }\left({ }^{\circ} \mathrm{C}\right)\end{array}$ & $50-4.5$ & 5.2 & 5.71 \\
Pour point $\left({ }^{\circ} \mathrm{C}\right)$ & 78 & 175 & 180 \\
\hline
\end{tabular}

\section{Conclusion}

In this study, we have reported the conversion efficiency of marine microalga $N$. oculata oil to biodiesel using immobilized lipase in a solvent-free system with methyl acetate as the acyl acceptor. On studying the effects of different parameters influencing the process, an effective conversion rate of $95.68 \%$ was observed. The optimized reaction conditions were $1.5 \mathrm{~g}$ immobilized lipase, 1:12 oil/methyl acetate molar ratio, $4 \%$ water $(\mathrm{w} / \mathrm{w}), 35^{\circ} \mathrm{C}, 250 \mathrm{rpm}$ and $60 \mathrm{~h}$. The study revealed the potentiality of encapsulated lipase in transesterification due to its high stability and efficient activity after repeated usage. The present work is more advantageous than previous investigations, as it is a solvent-free system using only methyl acetate as the acyl acceptor, resulting in triacetin as the by-product that could be useful in various applications. The process also proved to be environmentally friendly and cost-effective due to the reusability of the immobilized beads.

Acknowledgments The authors gratefully acknowledge the Department of Chemical Engineering, Annamalai University, for providing the necessary facilities to successfully complete this research work.

Conflict of interest The authors declare that there is no conflict of interest.

Open Access This article is distributed under the terms of the Creative Commons Attribution License which permits any use, distribution, and reproduction in any medium, provided the original author(s) and the source are credited.

\section{References}

Ali A, Kaur M, Mehra U (2011) Use of immobilized Pseudomonas sp. as whole cell catalyst for the transesterification of used cotton seed oil. J Oleo Sci 60(1):7-10

Al-Zuhair S, Ling FW, Jun LS (2007) Proposed kinetic mechanism of the production of biodiesel from palm oil using lipase. Process Biochem 42:951-960

Antczak MS, Kubiak A, Antczak T, Bielecki S (2009) Enzymatic biodiesel synthesis: key factors affecting efficiency of the process: review. Renew Energy 34:1185-1194
Ashokkumar V, Rengasamy R (2012) Mass culture of Botryococcus braunii Kutz. under open raceway pond for biofuel production. Bioresour Technol 104:394-399

Ban K, Hama S, Nishizuka K, Kaieda M, Matsumoto T, Kondo A, Noda H, Fukuda H (2002) Repeated use of whole-cell biocatalysts immobilized within biomass support particles for biodiesel fuel production. J Mol Catal B Enzym 17:157-165

Bisen PS, Sanodiya BS, Thakur GS, Baghel RK, Prasad GBKS (2010) Biodiesel production with special emphasis on lipase-catalyzed transesterification. Biotechnol Lett 32:1019-1030

Bligh EG, Dyer WJ (1959) A rapid method of total lipid extraction and purification. Can J Biochem Physiol 37:911-917

Burkert JFM, Maugeri F, Rodrigues MI (2004) Optimization of extracellular lipase production by Geotrichum sp. using factorial design. Bioresour Technol 91:77-84

Chisti Y (2007) Biodiesel from microalgae. Biotechnol Advan 25:294-306

Dizge N, Keskinler B (2008) Enzymatic production of biodiesel from canola oil using immobilized lipase. Biomass Bioenergy 32:1274-1278

Du W, Xu Y, Liu D, Zeng J (2004) Comparative study on lipasecatalysed transesterification of soybean oil for biodiesel production with different acyl acceptors. J Mol Catal B Enzym 3:125-129

Eevera T, Rajendran K, Saradha S (2009) Biodiesel production process optimization and characterization to assess the suitability of the product for varied environmental conditions. Renew Energy 34:762-765

Fukuda H, Hama S, Tamalampudi S, Fukumizu T, Miura K, Yamaji H (2006) Lipase localization in Rhizopus oryzae cells immobilized within biomass support particles for use as whole-cell biocatalysts in biodiesel-fuel production. J Biosci Bioeng 101:328-333

Gharat N, Rathod VK (2013) Ultrasound assisted enzyme catalyzed transesterification of waste cooking oil with dimethyl carbonate. Ultrason Sonochem 20:900-905

Gumbyte M, Makareviciene V, Sendzikiene E (2011) Esterification of by-products of biodiesel fuel production with methanol and technical glycerol using biocatalysts. Environ Res Eng Manag 2(56):28-34

Huang GH, Chen F, Wei D, Zhang XW, Chen G (2010) Biodiesel production by microalgal biotechnology. Appl Energy 87:38-46

Jegannathan KR, Yee LJ, Chan ES, Ravindra P (2010) Production of biodiesel from palm oil using liquid core lipase encapsulated in k-carrageenan. Fuel 89:2272-2277

Jeon DJ, Yeom SH (2010) Two-step bioprocess employing whole cell and enzyme for economical biodiesel production. Korean $\mathbf{J}$ Chem Eng 27(5):1555-1559

Jeong GT, Park DH (2008) Lipase-catalyzed transesterification of rapeseed oil for biodiesel production with tert-butanol. Appl Biochem Biotechnol 148:131-139

Kavardi SSS, Alemzadeh I, Kazemi A (2012) Optimization of lipase immobilization. IJE Trans C Aspects 25(1):1-9

Kawakami K, Oda Y, Takahashi R (2011) Application of a Burkholderia cepacia lipase immobilized silica monolith to batch and continuous biodiesel production with a stoichiometric mixture of methanol and crude Jatropha oil. Biotechnol Biofuels 4(42):1-11

Kim DG, La HJ, Ahn CY, Park YH, Oh HM (2011) Harvest of Scenedesmus sp. with bioflocculant and reuse of culture medium for subsequent high-density cultures. Bioresour Technol 102:3163-3168

Kumari A, Mahapatra P, Kumar Garlapati V, Banerjee R (2009) Enzymatic transesterification of Jatropha oil. Biotechnol Biofuels 2:1. doi:10.1186/1754-6834-2-1

Lai JQ, Hu ZL, Wang PW, Yang Z (2012) Enzymatic production of microalgal biodiesel in ionic liquid $[\mathrm{BMIm}]\left[\mathrm{PF}_{6}\right]$. Fuel 95:329-333

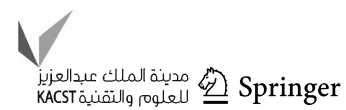


Leung DYC, Wu X, Leung MKH (2010) A review on biodiesel production using catalyzed transesterification. Appl Energy 87:1083-1095

Li Q, Yan Y (2010) Production of biodiesel catalysed by immobilized Pseudomonas cepacia lipase from Sapium sebiferum oil in micro-aqueous phase. Appl Energy 87:3148-3154

Lin Q, Gu N, Li G, Lin J, Huang L, Tan LL (2012) Effects of inorganic carbon concentration on carbon formation, nitrate utilization, biomass and oil accumulation of Nannochloropsis oculata CS 179. Bioresour Technol 111:353-359

Liu CH, Huang CC, Wang YW, Lee DJ, Chang JS (2012) Biodiesel production by enzymatic transesterification catalyzed by Burkholderia lipase immobilized on hydrophobic magnetic particles. Appl Energy 100:41-46

Lowry OH, Rosebrough NJ, Farr AL, Randal J (1951) Protein measurement with the folin-phenol reagent. J Biol Chem 193:265-275

Maceiras R, Vega M, Costa C, Ramos P, Marquez MC (2009) Effect of methanol content on enzymatic production of biodiesel from waste frying oil. Fuel 88:2130-2134

Maddikeri GL, Pandit AB, Gogate PR (2013) Ultrasound assisted interesterification of waste cooking oil and methyl acetate for biodiesel and triacetin production. Fuel Process Technol 116:241-249

Mutanda T, Ramesh D, Karthikeyan S, Kumari S, Anandraj A, Bux F (2011) Bioprospecting for hyper-lipid producing microalgal strains for sustainable biofuel production. Bioresour Technol 102:57-70

Ognjanovic N, Bezbradica D, Jugovic ZK (2009) Enzymatic conversion of sunflower oil to biodiesel in a solvent-free system: process optimization and the immobilized system stability. Bioresour Technol 100:5146-5154

Padilha GS, Curvelo Santana JS, Alegre RM, Tambourgi EB (2012) Extraction of Lipase from Burkholderia cepacia by PEG/ Phosphate ATPS and its Biochemical Characterization. Braz Arch Biol Technol 55:7-19

Pittman JK, Dean AP, Osundeko O (2011) The potential of sustainable algal biofuel production using waste water resources. Bioresour Technol 102:17-25

Rodriques RC, Zachia Ayub MA (2011) Effects of the combined use of Thermomyces lanuginosus and Rhizomucor miehei lipases for the transesterification and hydrolysis of soybean oil. Process Biochem 46:682-688

Ruzich NI, Bassi AS (2011) Proposed Kinetic mechanism of biodiesel production through lipase catalysed interesterification with a methyl acetate acyl acceptor and ionic liquid [BMIM] $\left[\mathrm{PF}_{6}\right]$ cosolvent. Can J Chem Eng 89:166-170

Salum TFC, Villeneuve P, Barea B, Yamamoto CI, Cocco LC, Mitchell DA, Krieger N (2010) Synthesis of biodiesel in column fixed-bed bioreactor using the fermented solid produced by Burkholderia cepacia LTEB11. Process Biochem 45:1348-1354

Sathasivam S, Manickam A (1996) Biochemical methods, revised 2nd edn. New Age International Pvt Ltd, New Delhi, pp 23-25

Shao P, Meng X, He J, Sun P (2008) Analysis of immobilized Candida rugosa lipase catalyzed preparation of biodiesel from rapeseed soapstock. Food Bioprod Process 86:283-289

Shimada Y, Wantanable Y, Samukawa T, Sugihara A, Noda IL, Fukuda II, Tominaga Y (1999) Conversion of vegetable oil to biodiesel using immobilized Candida antarctica lipase. J Am Oil Chem Soc 76:789-793

Sivaramakrishnan R, Muthukumar K (2012) Isolation of thermostable and solvent-tolerant Bacillus sp. lipase for the production of biodiesel. Appl Biochem Biotechnol 166:1095-1111
Su EZ, Zhang MJ, Zhang JG, Gao JF, Wei DZ (2007) Lipasecatalyzed irreversible transesterification of vegetable oils for fatty acid methyl esters production with dimethyl carbonate as the acyl acceptor. Biochem Eng J 36:167-173

Suganya T, Renganathan S (2012) Optimization and kinetic studies on algal oil extraction from marine macroalgae Ulva lactuca. Bioresour Technol 107:319-326

Surendhiran D, Vijay M (2012) Microalgal biodiesel: a comprehensive review on the potential and alternative Biofuel. Res J Chem Sci 2(11):71-82

Surendhiran D, Vijay M (2014a) Exploration on Bioflocculation of Nannochloropsis oculata using response surface methodology for biodiesel production. Sci World J. doi:10.1155/2014/202659

Surendhiran D, Vijay M (2014b) Effect of various pretreatment for extracting intracellular lipid from Nannochloropsis oculata under nitrogen replete and depleted conditions. ISRN Chemical Engineering. doi:10.1155/2014/536310

Tamalampudi S, Talukder MR, Hama S, Numata T, Kondo A, Fukuda H (2008) Enzymatic production of biodiesel from Jatropha oil: a comparative study of immobilized-whole cell and commercial lipases as a biocatalyst. Biochem Eng J 39:185-189

Tran DT, Yeh KL, Chen CL, Chang JS (2012) Enzymatic transesterification of microalgal oil from Chlorella vulgaris ESP-31 for biodiesel synthesis using immobilized Burkholderia lipase as the biocatalyst. Bioresour Technol 108:119-127

Tran DT, Chen CL, Chang JS (2013) Effect of solvents and oil content on direct transesterification of wet oil-bearing microalgal biomass of Chlorella vulgaris ESP-31 for biodiesel synthesis using immobilized lipase as the biocatalyst. Bioresour Technol 135:213-221

Umdu ES, Tuncer M, Seker E (2009) Transesterification of Nannochloropsis oculata microalga's lipid to biodiesel on $\mathrm{Al}_{2} \mathrm{O}_{3}$ supported $\mathrm{CaO}$ and $\mathrm{MgO}$ catalysts. Bioresour Technol 100:2828-2831

Usai EM, Gualdi E, Solinas V, Battistel E (2010) Simultaneous enzymatic synthesis of FAME and triacetyl glycerol from triglycerides and methyl acetate. Bioresour Technol 102:7707-7712

Vandamme D, Foubert I, Meesschaert B, Muylaert K (2010) Flocculation of microalgae using cationic starch. J Appl Phycol 22:525-530

Vimalarasan A, Pratheeba N, Ashokkumar B, Sivakumar N, Varalakshmi P (2011) Production of biodiesel from cyanobacteria (Oscillatoria annae) by alkali and enzyme mediated transesterification. J Sci Ind Res 70:959-967

Widjaja A, Chien CC, Ju YH (2009) Study of increasing lipid production from fresh water microalgae Chlorella vulgaris. J Taiwan Inst Chem Eng 40:13-20

Xiao M, Intan R, Obbard JP (2010) Biodiesel production from Microalgae oil-lipid feedstock via immobilized whole-cell biocatalysis. In: Proceedings of third international symposium on energy from biomass and waste, Venice, Italy, pp 8-11

Xu Y, Du W, Liu D, Zeng J (2003) A novel enzymatic route for biodiesel production from renewable oils in a solvent-free medium. Biotechnol Lett 25:1239-1241

$\mathrm{Xu} \mathrm{Y,} \mathrm{Du} \mathrm{W,} \mathrm{Liu} \mathrm{D} \mathrm{(2005)} \mathrm{Study} \mathrm{on} \mathrm{the} \mathrm{kinetics} \mathrm{of} \mathrm{enzymatic}$ interesterification of triglycerides for biodiesel production with methyl acetate as the acyl acceptor. J Mol Catal B Enzym 32:241-245

Xu H, Miao X, Wu Q (2006) High quality biodiesel production from a microalga Chlorella protothecoides by heterotrophic growth in fermenters. J Biotechnol 126:499-507

Yoshida A, Hama S, Tamadani N, Noda H, Fukuda H, Kondo A (2012) Continuous production of biodiesel using whole-cell 
biocatalysts: sequential conversion of an aqueous oil emulsion into anhydrous product. Biochem Eng J 68:7-11

Zheng H, Yin J, Gao Z, Huang H, Ji X, Dou C (2011) Disruption of Chlorella vulgaris cells for the release of biodiesel-producing lipids: a comparison of grinding, ultrasonication, bead milling, enzymatic lysis, and microwaves. Appl Biochem Biotechnol 164:1215-1224
Zhila NO, Kalacheva GS, Volova TG (2005) Effect of nitrogen limitation on the growth and lipid composition of the green alga Botryococcus braunii Kutz IPPAS H-252. Russ J Plant Physiol 52:357-365 